\title{
Will They Use What You Taught Them? Course-Embedded Assessment Of Accounting Students' Information Technology Self-Efficacy
}

John W. Moore, (Email: jmoore@vsu.edu), Virginia State University Cheryl E. Mitchem, Virginia State University

\begin{abstract}
This paper provides a model of course-embedded assessment for use in an undergraduate Accounting Information Systems course, and reports the results obtained from implementation. The profession's educational objectives are mapped to specific computer skills and assignments, to provide direct evidence of learning outcomes. Indirect evidence of learning is provided by data collected with computer self-efficacy instrumentation. The paper addresses an important issue for persons entering the profession, in that they may have learned to use specific computer applications, but may lack the confidence in their own ability to use these skills. This may impact their ability to gain employment, or to maintain employment in accounting. The data collected may be employed to assess how well an AIS course supports the mission of its school, by demonstrating the acquisition of IT skills and the necessary self-efficacy to use those skills.
\end{abstract}

\section{INTRODUCTION}

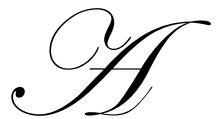

s proficient computer use has come to be expected in accounting jobs, students' beliefs in their ability to use computer technologies effectively, and their attitudes toward computers, have become critical factors in their professional success. Social cognitive theory (Bandura, 1977, 1997) posits that an individual's "perceived self-efficacy refers to beliefs in one's power to produce given levels of attainment. A self-efficacy assessment (by an individual) therefore includes both the affirmation of capability and the strength of that belief" (Bandura, 1997:382). An individual's self-efficacy can affect their interest in learning about computer systems (Stone, Arunachalam, and Chandler, 1996); their proficiency in using computers (Davis, Bagozzi, and Warshaw, 1989; Mills, 1997; Walters and Necessary, 1996) and their ability to obtain or maintain employment (Walters and Necessary, 1996). Stoner notes the effect this can have on students: "All too often students fail to thrive in computer-based work, not because of a lack of skills but because of a lack of confidence in the skills they have." (Italics added. 1999:234)

In spite of this attention, there is a small body of work examining the role of self-efficacy in computing behavior (Burkhardt and Brass, 1990; Compeau, Higgins, and Huff, 1999; Gist, Schwoerer, and Rosen, 1989; Henry and Stone, 2003; Johnson and Marakas, 2000; Kinsie, Delcourt, and Powers, 1994; and Martoccio and Judge, 1997). To our knowledge, there is no work concerning the use of self-efficacy as an assessment tool.

This paper addresses one of the main issues in why some students are not successful in computer-based work, by incorporating computer self-efficacy measurement along with instruction and assignments in four computer applications in an undergraduate Accounting Information Systems (AIS) course. It employs an instrument for application-specific changes in students' willingness to use what they learned in class (computer self-efficacy). Together the steps outlined in the paper provide a course-embedded assessment plan, with both direct and indirect 
evidence of learning outcomes, to offer a method of assessing the class's contribution to departmental and school objectives. A number of papers on computer self-efficacy use short time periods over which to measure selfefficacy; this paper tested changes in computer self-efficacy over a three-month period.

The remainder of the paper is organized as follows: Section II discusses assessment plans and self-efficacy. Section III describes the design of the study. Section IV presents the results obtained and Section V contains the conclusions.

\section{ASSESSMENT PLANS AND SELF-EFFICACY}

\section{Developing assessment plans to incorporate behavioral objectives, computer skills, and computer self-efficacy}

In this section we describe how our plan satisfies two complementary goals of accounting assessment. It provides two different course-embedded assessments, so that the assessment measures current computer skills, and it maps the profession's behavioral objectives of accounting education into discrete, measurable computer assignments. Secondly, it incorporates the important construct of self-efficacy into a separate pretest-posttest assessment of students' beliefs in their abilities to use the computer skills they have just been taught. Self-efficacy “....reflects an individual's confidence in his/her ability to perform the behavior required to produce specific outcomes and is thought to directly impact the choice to engage in a task, as well as the effort that will be expended and the persistence that will be exhibited" (Kinzie, Delcourt, and Powers, 1994:747).

First we discuss the use of behavioral objectives as the foundation for the plan, followed by the role of selfefficacy in assessment.

Among the objectives of the AIS class are four which have been adopted from the Accounting Education Change Commission. The AECC promulgated a series of objectives for the education of accountants which were classified as cognitive, affective, or behavioral. The AECC's definition of behavioral objectives suggests that there are numerous skills capable of being taught with or augmented with the use of computers and related technology:

Behavioral objectives generally include some of the so-called "softer" skills, and encompass the following: criticalthinking skills, problem-solving ability, effective writing, effective oral communication, including both listening and speaking skills, quantitative analysis, leadership skills, team-building skills, computer literacy, library and information-technology competence, and values awareness (Baker et al., 1994:107).

The assessment plan related the profession's relevant educational objectives to the types of tasks that accountants perform with computers, and to using typical software to accomplish these tasks. Table 1 begins (from the left) with the behavioral objectives from the AECC's Position Statement No. 1 we believed relevant to the AIS course. For each unobservable objective there follows a skill to represent it. Students completed one or two assignments for a grade in each of these to demonstrate what had been learned. The example software column lists the programs and reference databases students received training on and used to complete assignments. Finally the skills given in the righthand column agree with the computer skill grouping from the American Accounting Association's Comprehensive List of Soft Skills (Calderon, Green, and Harkness, 2003:7).

Students graduating from our program go to work as entry-level accountants. The types of assignments noted in Table 1 were intended to simulate professional work assignments. In a survey of over 4,000 CPAs, Prawitt, Romney, and Zarowin (1997) reported that 98\% of CPAs used spreadsheets, 52\% used presentation graphics programs, and about 50\% used a database program in their practice work. The products they used were overwhelmingly from the Microsoft Office Professional suite (Excel, Access, and PowerPoint). We used the same products these practitioners did, and we added the use of research or reference databases such as are found in university libraries or a larger CPA/consulting firm. These included Lexis/Nexis, Thomson Research, ABI/Inform, and Mergent Online. We did not teach nor test the use of tax research databases nor accounting general ledger programs, as these are taught in other accounting courses. 


\begin{tabular}{|c|c|c|c|c|}
\hline $\begin{array}{l}\text { Behavioral } \\
\text { Objectives }\end{array}$ & Representative Skills & $\begin{array}{l}\text { Assignments/ } \\
\text { Assessment Tasks }\end{array}$ & Example Software & Computer Skill \\
\hline $\begin{array}{l}\text { Communication } \\
\text { skills }\end{array}$ & $\begin{array}{l}\text { Ability to present, discuss, } \\
\& \text { defend views } \\
\text { effectively }\end{array}$ & $\begin{array}{l}\text { Flowcharting } \\
\text { internal controls } \\
\text { Case presentations }\end{array}$ & $\begin{array}{l}\text { M/S PowerPoint } \\
\text { M/S Word }\end{array}$ & $\begin{array}{l}\text { Using Presentation } \\
\text { Graphics }\end{array}$ \\
\hline $\begin{array}{l}\text { Communication } \\
\text { skills }\end{array}$ & $\begin{array}{l}\text { Ability to locate, obtain, } \\
\text { organize, report, \& use } \\
\text { information from human, } \\
\text { print, \& electronic sources } \\
\text { (Library \& IT competence) }\end{array}$ & $\begin{array}{l}\text { Merger \& } \\
\text { acquisition case } \\
\text { Article reviews of } \\
\text { current topics }\end{array}$ & $\begin{array}{l}\text { Library databases (e.g., } \\
\text { Lexis/Nexis, Mergent } \\
\text { Online, Proquest, S\&P } \\
\text { NetAdvantage) } \\
\text { Internet } \\
\text { Metacrawler }\end{array}$ & $\begin{array}{l}\text { Online Research } \\
\text { Queries }\end{array}$ \\
\hline $\begin{array}{l}\text { Accounting } \\
\text { knowledge }\end{array}$ & $\begin{array}{l}\text { Identify, summarize, \& } \\
\text { analyze financial data in } \\
\text { business organizations }\end{array}$ & $\begin{array}{l}\text { Merger \& } \\
\text { acquisition case } \\
\text { PivotTables }\end{array}$ & M/S Excel & $\begin{array}{l}\text { Using Spreadsheet } \\
\text { Tools }\end{array}$ \\
\hline $\begin{array}{l}\text { Accounting } \\
\text { knowledge }\end{array}$ & $\begin{array}{l}\text { Concepts \& principles of } \\
\text { information system design } \\
\& \text { use }\end{array}$ & $\begin{array}{l}\text { Construct a simple } \\
\text { accounting system } \\
\text { using a relational } \\
\text { database }\end{array}$ & M/S Access & $\begin{array}{l}\text { Using Database } \\
\text { Tools }\end{array}$ \\
\hline
\end{tabular}

Students received training in the four computer skills given in Table 1, combining enactive mastery (handson) training and behavior modeling precepts (discussed under self-efficacy). The assignments in Table 1 and discussed in the results section were predominantly completed in class. The instructor critiqued each, offering comment and suggestions if needed. Students then made improvements or corrections and submitted their work for a grade. This sequence provided direct evidence that one of the course's objectives had been satisfied. Figure 1 below depicts on a timeline the six components of the assessment plan. The components numbered two through five represent this sequence beginning with hands-on instruction and ending with the assignment of grades.

Figure 1 shows as the first and last components the collection of data (pretest and posttest) regarding students' assessment of their self-efficacy with respect to each of the four computer skills they learned in the class. The pretest and posttest computer self-efficacy questionnaires represent indirect evidence of a learning outcome. For purposes of accreditation, direct evidence is preferred, but it may be necessary to collect indirect evidence about the course or program being assessed (Bayes, 2004).

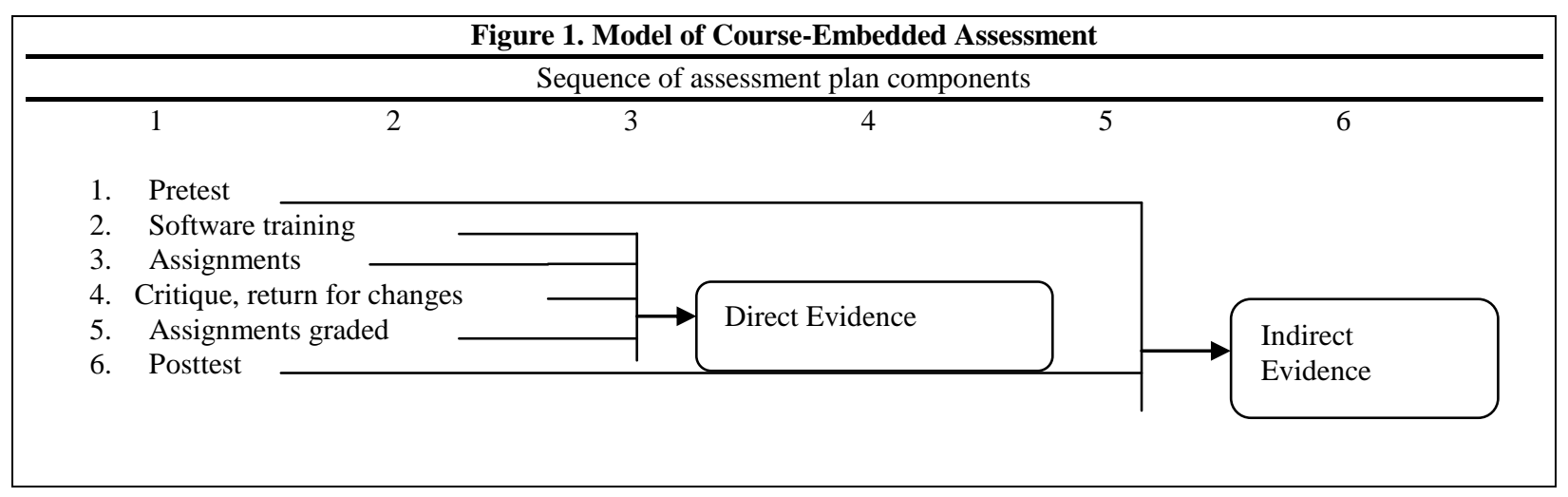

\section{Self-Efficacy}

As Figure 1 indicates, we used a computer self-efficacy assessment instrument at the beginning of the class, prior to any software training or computer work, and again at the end of the class to collect evidence as to whether or 
not students' assessment of their computer self-efficacy had changed. Using self-efficacy changes to assess the effectiveness of the AIS class provides indirect evidence of learning outcomes, as students judge that they can accomplish more with these computer skills than they believed possible at the start of the class.

The impetus for this approach came from recent research into the effects that the increased emphasis on computers and information technology has on accounting education (David, McCracken and Reckers, 2003). These changes will likely affect students' perceptions of their accounting education. Stone, Arunachalam and Chandler observed that "...of potentially equal importance, are the effects of changes in accounting education on students' beliefs in their ability to accomplish accounting related tasks (i.e., their "accounting-related self-efficacy") and students' feelings about computers and computer-based technology" (1996:346). Walters and Necessary (1996) have shown a relationship between individuals' perceptions of the importance of technology and proficiency in using technology. Negative attitudes towards computers may stop individuals from gaining access to or effectively using computers in the workplace and may even limit their opportunities for getting and holding employment (Walters et al., 1996).

Accounting educators expect routine computer use by students. However, the instructors are also shaping attitudes that will affect their students' control over technology after graduation. Thus, it is necessary to both enhance and measure students' self-efficacy with respect to computer technologies (Ertmer, Evenbeck, Cennamo, and Lehman, 1994; Kinzie et al., 1994). Because of the importance of information technology proficiency in the accounting profession, students' perceptions of confidence towards technology are critical to ensure their successful utilization of technology and related software (Mills, 1997).

Albert Bandura, founder of the self-efficacy concept, explained the idea thusly: "Perceived self-efficacy refers to beliefs in one's power to produce given levels of attainment. A self-efficacy assessment, therefore, includes both the affirmation of capability and the strength of that belief" (1997:382). Individuals with high self-efficacy will put more effort into a task; they will persevere longer; and they will realize higher levels of accomplishment than individuals with lower self-efficacy.

Information about a person's self-efficacy has four sources (Bandura, 1997), the first two of which are relevant to this discussion. These are enactive mastery experiences, vicarious experience, verbal persuasion, and physiological and affective states. Enactive mastery (hands-on) experiences are actual proof that an individual can succeed at a task, and so are the strongest source. As students experience more successes with a computer, their belief in self-efficacy will generally increase. Consequently, actual hands-on training serves two purposes - students can build up confidence in their ability as well as learn the skill itself. If they are taught the computer skills in the AIS class, where they may ask questions and be coached, they will likely have a successful experience, and this will strengthen their self-efficacy. It may also reduce the amount of unsuccessful efforts, which would reduce selfefficacy, discouraging them from using the technology (Compeau and Higgins, 1995).

The second source of self-efficacy information is vicarious experience. In a classroom, a student seeing someone else modeling the desired behavior will believe that he or she can also perform successfully (Bandura, 1997:87). To be effective as a learning tool, the greater the similarity between the model and the student, the more effective will be the experience. This suggests that having another student model successful computer work is more useful than having an instructor alone model the behavior.

\section{DESIGN AND INSTRUMENTATION}

The research design is a one group, two measurement protocol in which all students receive the treatment. Pretest and posttest questionnaires were based on the Self-Efficacy for Computer Technologies instrument (SCT) (Kinzie et al., 1994). The SCT measures confidence in using a number of applications, including spreadsheets, databases, and library reference databases (Which may be either online or on CD-ROM). An additional scale was developed by the authors to include presentation graphics programs. One objective of the class is to teach and improve students' abilities in using applications that are related to accounting work, so an instrument that focused on 
application-specific computer self-efficacy (CSE) was appropriate, as compared to instruments which measure overall computer self-efficacy (Johnson and Marakas, 2000). For each computer skill there is a scale with seven to nine items, all of the form "I feel confident..." and then requesting a response to the specific item, such as "...selecting search terms for a database literature search." Possible responses are on a four-point Likert and include these choices (point values in parentheses): "strongly disagree" (value $=1$ ); "somewhat disagree" (value $=2$ ); "somewhat agree" (value $=3$ ); and "strongly agree" (value $=4$ ).

The internal consistency reliability estimates (Cronbach's alpha) for each of the scales are: Electronic Spreadsheets, 0.9015; Database, 0.9763; Library Reference Databases, 0.9767; and Presentation Graphics, 0.9721. These first three scores agree with those reported by Kinsie et al. (1994). The new scale for presentation graphics has a similar high alpha score. Hair, Anderson, Tatham, and Black (1998:118) suggest the lower acceptable limit for this test is .70. A Bonferroni adjustment of the confidence level was used in the paired variable means tests, to protect against multiple testing.

\section{RESULTS}

Several factors must be mentioned as potential limitations on this research. Since we cannot control outside influences affecting students' learning of computer technologies (e.g., in other classes, on the job, or at home) we cannot prove that the assignments were solely responsible for the improvements in self-efficacy. However, there are few reasons for the students to have or use many of the applications. Examples of these are database and spreadsheets, because these are more professional tools rather than recreational tools or communications devices. The improvements on the library reference databases scale likewise cannot be proven to be only a result of the project, because this reference tool is widely available in local county libraries and the university library, and is bundled as a reference with many new computer sales. However, the question was worded to elicit responses to business-oriented databases.

A limitation of the design is the lack of a control group. Due to the small number of students participating, there were inadequate numbers enrolled to allow for this feature.

General ledger and tax programs are used in other classes and were not included in this research.

\section{Demographic Data}

The students who participated in this survey were attending a small public university, and were all business school students. Most entered university directly from high school. Ages ranged from 19 to 47 (mean $=23$ years). The gender split was 32.5 percent males $(n=37) ; 67.5$ percent females $(n=77)$. These 114 students were enrolled in a junior-level accounting information systems course, and completed both a pretest and posttest survey, of a total of 176 students who completed the class. This yielded a 65\% participation rate. Sixty-six percent were juniors, 33 percent were seniors, and the balance was post-degree students. Virtually all were accounting majors. The survey covers eight semesters' administration of this instrument.

Students reported computer usage ranging from one to twenty years. The mean usage of computers was 8.7 years for men, and 9.7 years for women with an overall mean of 9.4 years. Table 2 provides data on students' computer and parental background. A majority of the students reported they had used a computer both at home and at work. They also reported they had pre-high school experience using computers, and that their parents used a computer on the job. 


\begin{tabular}{|l|c|c|c|}
\hline \multicolumn{3}{|c|}{ Table 2. Computer Use, Experience, and Education. } & No \\
\hline Variable & Yes & $N$ \\
\hline Do you use a computer at home? & $79.8 \%$ & $20.2 \%$ & 114 \\
\hline Do you use a computer on your job? & $71.7 \%$ & $28.3 \%$ & 113 \\
\hline Did you have any classroom computer experience prior to high school? & $69.3 \%$ & $30.7 \%$ & 114 \\
\hline Does either of your parents use a computer on his or her job? & $64.9 \%$ & $35.1 \%$ & 114 \\
\hline Do either of your parents have a college degree? & $43.0 \%$ & $57.0 \%$ & 114 \\
\hline Do you already have a college degree? & $8.8 \%$ & $91.2 \%$ & 114 \\
\hline
\end{tabular}

\section{Experience with Computer Technologies}

As a preliminary measure, students were asked on the pretest to describe their experience in using the four computer technologies that were to be taught. Table 3 below shows that many students used the technologies in high school. Spreadsheets were encountered in high school more often than the other products. A majority of the students first used databases, graphics, and library reference databases in college. The number of responses varies in the following tables due to non-responses.

\begin{tabular}{|l|c|c|c|c|c|c|}
\hline \multicolumn{7}{|c|}{ Table 3. First experience with computer technologies. } \\
\hline Variable & $\begin{array}{c}\text { First used before } \\
\text { high school }\end{array}$ & $\begin{array}{c}\text { First used in } \\
\text { high school }\end{array}$ & $\begin{array}{c}\text { First used in } \\
\text { college }\end{array}$ & $\begin{array}{c}\text { First used } \\
\text { at home }\end{array}$ & $\begin{array}{c}\text { First used } \\
\text { on a job }\end{array}$ & $\begin{array}{c}N \\
\text { job }\end{array}$ \\
\hline Spreadsheet & $4.5 \%$ & $48.6 \%$ & $39.6 \%$ & $0.9 \%$ & $6.3 \%$ & 111 \\
\hline Database & $6.0 \%$ & $33.3 \%$ & $46.0 \%$ & $0 \%$ & $12.0 \%$ & 100 \\
\hline Library databases & $6.5 \%$ & $30.4 \%$ & $52.2 \%$ & $7.6 \%$ & $3.3 \%$ & 92 \\
\hline Graphics & $3.0 \%$ & $32.7 \%$ & $56.4 \%$ & $3.0 \%$ & $5.0 \%$ & 101 \\
\hline
\end{tabular}

\section{Frequency of use}

A paired variable t-test of mean differences was performed on the pretest and posttest frequency of use data to determine if there was a difference in students' frequency of use over the semester. The result was that for three of the four technologies surveyed, students' frequency of usage increased significantly. (The values assigned for scoring were: several times a week $=1$; once a week $=2,1-3$ times a month $=3$, and do not use $=4$.) As shown in Table 4, students believed that their usage of all four technologies increased, and these were significant changes for all but library reference databases.

\begin{tabular}{|l|c|c|c|c|}
\hline \multicolumn{5}{|c|}{ Table 4. Paired variables t-test for changes in frequency of use. } \\
\hline Variable & Pretest Mean & Posttest Mean & $\mathrm{N}$ & 2-tail Significance \\
\hline Use Spreadsheets & 1.98 & 1.56 & 105 & $.000^{* * *}$ \\
\hline Use Relational Database Management Systems & 2.73 & 2.02 & 103 & $.000^{* * *}$ \\
\hline Use Library Reference Databases & 2.71 & 2.50 & 101 & .088 \\
\hline Use Graphics Programs & 2.82 & 2.24 & 103 & $.000^{* * *}$ \\
\hline
\end{tabular}

*Significant at .05; **significant at .01; ***significant at .001

We next report on the results of the Self-Efficacy for Computer Technologies survey. This contains four scales measuring students' comfort in using common business applications. The items responded to are listed at the left of each scale, and the 2-tailed significance of the t-statistic is in the box opposite the item. Using a two-tailed paired variable test of mean differences, with significance at the .05 level or less, the results obtained were as follows: The scale is $1=$ strongly disagree, $2=$ slightly disagree, $3=$ slightly agree, and $4=$ strongly agree. 


\section{Electronic Spreadsheets Scale}

Spreadsheets are used for many purposes in the profession. Increasing students' ability to use this versatile and powerful program requires considerable practice. Students completed a web-based tutorial, participated in inclass exercises, produced financial statements in a spreadsheet, and used the PivotTable function to analyze financial data. Stronger students were engaged by the PivotTable and its analytic capability, and produced well-supported analyses, while the weaker ones had difficulty with the assignment.

Significant results were obtained on the more involved spreadsheet functions (shown below). The two functions not showing a significant improvement (printing and saving a spreadsheet file) are possibly due to the Windows file menu used on the Office suite of programs: students have had considerable prior experience with these functions.

\begin{tabular}{|c|c|c|c|c|}
\hline Variable & Pretest Mean & Posttest Mean & $N$ & $\begin{array}{l}\text { 2-tail } \\
\text { Sig. }\end{array}$ \\
\hline ...formatting the rows and columns of a spreadsheet" & 3.68 & 3.84 & 114 & $.002 * *$ \\
\hline ...naming the columns and rows in a spreadsheet" & 3.68 & 3.84 & 114 & $.010 * *$ \\
\hline $\begin{array}{l}\text {...entering appropriate formulas for calculation in a } \\
\text { spreadsheet" }\end{array}$ & 3.40 & 3.66 & 114 & $.000 * * *$ \\
\hline ...entering data in a spreadsheet" & 3.74 & 3.83 & 114 & $.047 *$ \\
\hline ...editing previous spreadsheet files" & 3.54 & 3.80 & 114 & $.000 * * *$ \\
\hline ...printing out the spreadsheet" & 3.82 & 3.87 & 114 & .241 \\
\hline ...saving a spreadsheet file" & 3.87 & 3.89 & 114 & 657 \\
\hline
\end{tabular}

*significant at $.05 ; * *$ significant at $.01 ; * * *$ significant at .001

\section{Database Management System Scale}

The database scale examines students' attitudes towards using a database program. The assignments include readings, exercises, and the construction of a simple accounting system. In doing this they learn documentation skills, writing queries, and the implementation of internal controls.

The database scale contains seven items. Results obtained show significant improvements in self-efficacy in all seven areas:

\begin{tabular}{|l|c|c|c|c|}
\hline \multicolumn{4}{|c|}{ Table 6. Database Management System Scale: "I feel confident... } \\
\hline Variable & $\begin{array}{c}\text { Pretest } \\
\text { Mean }\end{array}$ & $\begin{array}{c}\text { Posttest } \\
\text { Mean }\end{array}$ & 2-tail Sig. \\
\hline ...formulating the data fields in a database" & 2.65 & 3.34 & 114 & $.000^{* * *}$ \\
\hline ...naming data fields in a database" & 2.74 & 3.46 & 114 & $.000^{* * *}$ \\
\hline ...entering records in a database" & 2.78 & 3.45 & 113 & $.000^{* * *}$ \\
\hline ...searching records in a database with specific terms" & 2.71 & 3.30 & 112 & $.000^{* * *}$ \\
\hline ...sorting records in a database" & 2.69 & 3.30 & 114 & $.000^{* * *}$ \\
\hline ...printing out records in a database" & 2.94 & 3.56 & 114 & $.000^{* * *}$ \\
\hline ...saving database files" & 3.01 & 3.57 & 113 & $.000^{* * *}$ \\
\hline
\end{tabular}

*significant at .05; **significant at .01; ***significant at .001 


\section{Library Reference Databases Scale}

The ability to identify and use information resources is paramount in the accounting profession. Training in this area was conducted by a reference librarian, who was also available to help students in the library. Students were assigned to research a proposed merger and acquisition case in the transportation industry. They used various features of the Thomson Research financial statements database (for individual companies' text-searchable statements), the Standard \& Poor's Net Advantage database (for industry-specific commentary and analysis), and Lexis/Nexis (for regulatory data). They also were assigned article reviews to use in learning the use of periodicals databases, including ABI/Inform and Lexis-Nexis. Students' self-efficacy with respect to using library databases as research and reference tools showed significant improvements in all areas.

\begin{tabular}{|c|c|c|c|c|}
\hline \multicolumn{5}{|c|}{ Table 7. Library Reference Databases Scale: "I feel confident... } \\
\hline Variable & $\begin{array}{l}\text { Pretest } \\
\text { Mean }\end{array}$ & $\begin{array}{l}\text { Posttest } \\
\text { Mean }\end{array}$ & $N$ & 2-tail Sig. \\
\hline $\begin{array}{l}\text {...using a database on compact disc, such as Compact Disclosure, ABI } \\
\text { Inform/Proquest, EconLit, Eric, etc." }\end{array}$ & 2.42 & 2.78 & 112 & $.001 * * *$ \\
\hline ...selecting the right database on compact disc and starting a literature search" & 2.46 & 2.87 & 112 & $.000 * * *$ \\
\hline ...selecting search terms for a database literature search" & 2.59 & 2.93 & 112 & $.001 * * *$ \\
\hline ...getting into a database on compact disk and starting a literature search" & 2.52 & 2.91 & 112 & $.000 * * *$ \\
\hline $\begin{array}{l}\text {...using descriptors from a database literature search to obtain new search } \\
\text { items" }\end{array}$ & 2.35 & 2.85 & 110 & $.000 * * *$ \\
\hline ...using the print function in a database search on compact disc" & 2.67 & 3.10 & 111 & $.000 * * *$ \\
\hline ...selecting the right terms for a database financial reports search" & 2.36 & 2.88 & 112 & $.000 * * *$ \\
\hline $\begin{array}{l}\text {...getting into a database on compact disk and starting a financial reports } \\
\text { search" }\end{array}$ & 2.32 & 2.86 & 111 & $.000 * * *$ \\
\hline $\begin{array}{l}\text {...using descriptors from a database financial reports search to obtain new } \\
\text { search items" }\end{array}$ & 2.27 & 2.91 & 107 & $.000 * * *$ \\
\hline
\end{tabular}

*significant at $.05 ; * *$ significant at $.01 ; * * *$ significant at .001

\section{Graphics Program Scale}

A graphics scale was constructed to test self-efficacy with respect to presentation graphics software. On entering the accounting workforce, they will need to be able to present ideas to their colleagues and managers, and this extends their communication skills. Assignments completed included flowcharting internal controls and case presentations. Students' self-efficacy with respect to graphics packages showed significant improvement across all variables (below).

\begin{tabular}{|c|c|c|c|c|}
\hline \multicolumn{5}{|c|}{ Table 8. Graphics Scale: "I feel confident... } \\
\hline Variable & Pretest Mean & Posttest Mean & $N$ & 2-tail Sig. \\
\hline ...formatting the workspace in a graphics program" & 2.58 & 3.28 & 113 & $.000 * * *$ \\
\hline ...choosing a symbol to represent an action or object" & 2.72 & 3.37 & 113 & $.000 * * *$ \\
\hline ...placing the symbol on the workspace" & 2.77 & 3.42 & 112 & $.000 * * *$ \\
\hline ...linking several symbols together" & 2.60 & 3.38 & 112 & $.000 * * *$ \\
\hline ...adding text to a drawing" & 2.83 & 3.45 & 113 & $.000 * * *$ \\
\hline ...printing out the graphic image" & 2.96 & 3.55 & 113 & $.000 * * *$ \\
\hline ...saving the graphic file" & 2.96 & 3.58 & 113 & $.000 * * *$ \\
\hline
\end{tabular}

significant at $.05 ; * *$ significant at $.01 ; * * *$ significant at .001 


\section{CONCLUSIONS}

This study demonstrated that course-embedded assessment in the AIS course can provide both direct and indirect evidence of learning. Focusing on improving students' information technology self-efficacy may help to solve the issue of students who have learned the computer skills, but lack the confidence to use them. Removing this obstacle may be as important to their future success as teaching them specific computer skills.

\section{ACKNOWLEDGEMENTS}

The authors wish to thank Jacqueline Perry and participants at the 2004 AAA Mid-Atlantic and 2004 AAA Ohio regional meetings for commenting on earlier versions of this paper. Any remaining errors are the responsibility of the authors.

\section{REFERENCES}

1. American Accounting Association (AAA) Accounting Education Change Commission (AECC). 1990. Objectives of Education for Accountants: Position Statement Number One. Issues in Accounting Education 5(2): 307-312.

2. Baker, R., Bayer, F., Gabbin, A., Izard, D., Jacobs, F., and Polejewski, S. 1994. Summary of outcomes assessment. Journal of Accounting Education 12(2): 105-114.

3. Bandura, A. 1977. Self-efficacy: Toward a unifying theory of behavioral change. Psychological Review 84: 191-215.

4. Bandura, A. 1997. Self-Efficacy: The Exercise of Control. New York: W. H. Freeman and Company.

5. Bayes, P. A review of documented assessment practices of AACSB Accredited Programs. Sub-Committee Report. American Accounting Association Meeting, Orlando, Florida, August 8, 2004.

6. Burkhardt, M. and Brass, D. 1990. Changing Patterns or Patterns of Change: The Effects of a Change in Technology on Social Network Structure and Power. Administrative Science Quarterly 35(1): 104-127.

7. Calderon, T., Green, B., and Harkness, M. 2003. Best Practices in Accounting Program Assessment. Sarasota: Teaching and Curriculum Section, American Accounting Association.

8. Compeau D. and Higgins, C. 1995. Computer Self-Efficacy: Development of a Measure and Initial Test. MIS Quarterly (June): 189-211.

9. ___ a _ and Huff, S. 1999. Social Cognitive Theory and Individual Reactions to Computing Technology: A Longitudinal Study. MIS Quarterly 23(2): 145-158.

10. David, J, McCracken, H., and Reckers, P. 2003. Integrating Technology and Business Process Analysis into Introductory Accounting Courses. Issues in Accounting Education 18(4): 417-425.

11. Davis, F., Bagozzi, R., and Warshaw, P. 1989. User acceptance of computer technology: A comparison of two theoretical models. Management Science 35 (8): 982-1003.

12. Ertmer, P.A., Evenbeck, E., Cennamo, K. S., and Lehman, J. D. 1994. Enhancing Self-Efficacy for Computer Technologies Through the use of Positive Classroom Experiences. Educational Technology Research and Development 42 (3): 45-62.

13. Gist, M., Schwoerer, C. and Rosen, B. 1989. Effects of Alternative Training Methods on Self-Efficacy and Performance in Computer Software Training. Journal of Applied Psychology 74(6), 884-891.

14. Hair, J. F., Anderson, R. E., Tatham, R. L., and Black, W. C. 1998. Multivariate Data Analysis Fifth Edition Upper Saddle River: Prentice Hall.

15. Johnson, R. and Marakas, G. 2000. Research report: the role of behavioral modeling in computer skills acquisition: toward refinement of the model. Information Systems Research 11(4), 402.

16. Kinzie, M.B., Delcourt, M. A. B., and Powers, S. M. 1994. Computer Technologies: Attitudes and SelfEfficacy Across Undergraduate Disciplines. Research in Higher Education 35(6): 745-768.

17. Martocchio, J. and Judge, T. 1997. Relationship Between Conscientiousness and Learning in Employee Training: Mediating Influences of Self-Deception and Self-Efficacy. Journal of Applied Psychology 82(5), 764-773.

18. Mills, T. A. 1997. An examination of the relationship between accountants' scores on field independence 
and use of and attitude towards computers. Perception and Motor Skills 81, 715-20.

19. Prawitt, D., Romney, M. and Zarowin, S. 1997. A journal survey: The software CPAs use. Journal of Accountancy 184(5), 52(12).

20. Stone, D., Arunachalam, V., and Chandler, J. 1996. An empirical investigation of knowledge, skill, selfefficacy and computer anxiety in accounting education. Issues in Accounting Education 11(2): 345-376.

21. Stone, R. and Henry, J. 2003. The roles of computer self-efficacy and outcome expectancy in influencing the computer end-user's organizational commitment. Journal of End User Computing 15(1), 38(16).

22. Stoner, Greg. 1999. IT is part of youth culture, but are accounting undergraduates confident in IT? Accounting Education 8 (3), 217-237.

23. Walters, J. E. and Necessary, J. R. 1996. An attitudinal comparison toward computers between upperclassmen and graduating seniors. Education 116 (4), 623-31.

$\underline{\text { Notes }}$ 